\title{
Comparative Performance of Pangasianodon hypophthalmus (Sauvage, 1878) Culture in Cages and Ponds
}

\author{
Manish Kumar", Kiran Dube, V.K. Tiwari, A.K. Reddy and C.S. Chaturvedi \\ ICAR-Central Institute of Fisheries Education, Panch Marg, Off Yari Road, \\ Versova, Mumbai-400061, India \\ *Corresponding author
}

\section{A B S T R A C T}

The study was carried out for 210 days to compare the growth, survival, production and economic performance of Pangasianodon hypophthalmus in cages and ponds. The fingerlings of P.hypophthalmus $(71.47 \pm 0.84 \mathrm{~g}$ wt. and $18.83 \pm 0.52 \mathrm{~cm}$ length) were stocked at 50,60 and 70 fingerlings $/ \mathrm{m}^{3}$ in nine cages $\left(6 \times 4 \times 3 \mathrm{~m}^{3}\right)$ and they were stocked

Keywords

Pangasianodon hypophthalmus, Cage culture, Pond culture, Comparison.

\section{Article Info}

Accepted: 17 September 2017 Available Online: 10 October 2017 at 5,6 and 7 fingerlings $/ \mathrm{m}^{3}$ in nine ponds $\left(50 \times 30 \mathrm{~m}^{2}\right.$ and $1.2 \mathrm{~m}$ depth) following three treatments with triplicates for both cages and ponds. Fish were fed with commercial feed (32\% protein, Growel Feeds Pvt. Ltd.) initially at the rate of $5 \%$ of body weight to $1.75 \%$ of body weight at the end of the culture period. At the end of the experiment, average growth of $P$. hypophthalmus was recorded higher in cages $(1026.87 \pm 7.48 \mathrm{~g}$ and $46.25 \pm$ $0.94 \mathrm{~cm})$ as compared to ponds $(975.84 \pm 7.21 \mathrm{~g}$ and $45.06 \pm 0.79 \mathrm{~cm})$ in terms of final body weight and length. Likewise the specific growth rate (SGR) was also higher in cages $(1.27 \pm 0.007)$ than ponds $(1.25 \pm 0.008)$. The survival of fish showed better performance in cages $(90.91 \pm 0.93 \%)$, when compared to ponds $(78.0 \pm 0.87 \%)$. The production per unit volume recorded was much higher in cages $\left(55.91 \pm 0.47 \mathrm{~kg} / \mathrm{m}^{3}\right)$ than ponds $(4.56 \pm$ $0.04 \mathrm{~kg} / \mathrm{m}^{3}$ ) and therefore, net profit per unit volume achieved was too higher in cages ( $\square$ $\left.1254.00 \pm 24.12 / \mathrm{m}^{3}\right)$ than ponds $\left(\square 57.50 \pm 0.89 / \mathrm{m}^{3}\right)$. The better feed conversion ratio (FCR) was achieved in ponds $(1.47 \pm 0.01)$ when compared to cages $(1.63 \pm 0.011)$ whereas, the benefit cost ratio $(\mathrm{BCR})$ was found better in cages $(1.36 \pm 0.004)$ than ponds $(1.28 \pm 0.002)$. The benefit-cost analysis of this study suggests for adoption of cage culture, as it is more profitable than pond culture.

\section{Introduction}

Pangasianodon hypophthalmus is regarded as the third most important freshwater aquaculture species due to its fast growth and versatile feeding habit. Because of its obligate air-breathing nature and ability for ecocyclic production makes it highly suitable for species diversification to sustain freshwater fish production. Now a day it generally ranks behind only shrimp, salmon and tilapia as the largest aquaculture commodity produced in the world. P. hypophthalmus has immense economic importance in many countries of South and Southeast Asia, including India, Bangladesh, Thailand, Vietnam and Malaysia. The commercial culture and production of $P$. hypophthalmus has been expanded dramatically but recently the profit is decreasing bit by bit due to a number of reasons like increased feed cost and improper management practices. 
During 1997, P. hypophthalmus was introduced in India clandestinely via Bangladesh and farmers were adopted for culture in West Bengal. There has been much ebullience among fish breeders and farmers particularly in West Bengal, Andhra Pradesh and Chhattisgarh for its culture and propagation because of its remarkable growth rate. It was estimated that over 0.2 million tonnes of $P$. hypophthalmus catfish were produced in the country per annum (Lakra and Singh, 2010). National production of $P$. hypophthalmus in India accounts for 0.7 million tonnes (Singh and Lakra, 2012). The farmers generally preferred monoculture practices of this species in Krishna and West Godavari districts of Andhra Pradesh in big ponds ranging from 4 ha to 40 ha. It was found that there is a shift in culture practice from carps to pangasius in some of the areas in Andhra Pradesh. The total area for $P$. hypophthalmus culture was estimated to be around 20,000 ha covering roughly $15 \%$ of the total cultured area, which has been increasing over the years. The average culture production of $P$. hypophthalmus in tonnes/hectare/year are found to be higher than carp production in the same areas (Lakra and Singh, 2010). Its culture practice is growing rapidly in Andhra Pradesh, Bihar, Uttar Pradesh, Orissa, Maharashtra, Chhattisgarh, Tamil Nadu, Karnataka, and Kerala. But the culture of this fish has been largely restricted to land-based pond aquaculture systems.

Cage aquaculture has certain advantages over other aquaculture systems that are - use of existing reservoir resources, easiness of feeding, stocking and harvesting, lower expense associated with treating or preventing disease, relatively easier stocking management and monitoring compared with pond culture. Aquaculture in cage has some technical simplicity with that farms can be established or expanded, relatively lower capital cost, feeding, growth rate and health of stocked fishes can be monitored on a daily routine basis without much more disturbance and harvesting of cultured species would be easier and cost effective. In India, cage culture initially reported in 2002, when carps like Labeorohita and Cyprinuscarpio were cultured in cages installed in Powai lake, then Tor putitora and Tor Khudree were also cultured in cages installed in Walvan reservoir (Kohli et al., 2002, 2004). Central Institute of Fisheries Education, Mumbai has also practiced cage aquaculture in open water (Kohli et al., 2004). Cage culture of $P$. Hypophthalmus has been initiated in Govind Sagar reservoir (Chaturvedi et al., 2015).

Although, a good number of studies are undertaken for both pond culture and cage culture of P.hypophthalmus and it is also commercially practiced in all parts of the world, there is very scanty literature on the comparison of two aquaculture system in terms of growth, survival and production. Therefore, the present work is undertaken to compare the growth, survival, production and economic performance of $P$. hypophthalmusin cages and ponds.

\section{Materials and Methods}

The study was conducted for 210 days during October 2014 to May 2015in earthen ponds at Pench national fish seed farm and in floating net cages installed in Dhasai reservoir, Maharashtra. Nine earthen ponds, each of $1500 \mathrm{~m}^{2}$ area with an average depth of $1.2 \mathrm{~m}$ were prepared by conventional liming and fertilization and nine floating net cages $(6 \times 4$ x $3 \mathrm{~m}^{3}$ ) made of nylon cage net (30 mm mesh size), light galvanized iron conduit pipes (25 $\mathrm{mm}$ diameter), iron bar, 210 litre capacities HDPE empty sealed barrels, nylon twine, thin GI (Galvanized iron) wire and hard wooden planks (1" x 1 feet x 13 feet), were installed in reservoir. The feeding screen net was kept 
inside cage at some distance from cage net so that water can circulate easily and fishes might not be getting any disturbance in their movement.

The fingerlings of $P$. hypophthalmus $(71.47 \pm$ $0.84 \mathrm{~g}$ wt. and $18.83 \pm 0.23 \mathrm{~cm}$ length) were stocked in earthen ponds @ 5,6 and 7 fingerlings $/ \mathrm{m}^{3}$ with triplicate for each density and they were stocked@ 50, 60 and 70 fingerlings $/ \mathrm{m}^{3}$ in experimental cages following triplicate for each density. Feeding was done with commercially extruded floating feed $(4 \mathrm{~mm})$ containing a minimum of $32 \%$ protein, $4 \%$ fat and $5.5 \%$ fibre at the rate of $5 \%$ of their body weight at every 2 hour of interval in a day. After attaining an average size of $150 \mathrm{~g}$ in 30 days of culture, they were fed only three times $(9 \mathrm{am}, 1 \mathrm{pm}$ and $5 \mathrm{pm}$ ) at every four hour of interval in a day in cages and only two times (11 am and 4 pm) in ponds @ $4 \%$ of their body weight. After 120 days of culture, the fishes were having an average size of $500 \mathrm{~g}$, fed @ $3 \%$ of their body weight followed by $2 \%$ of body weight, which was then reduced to $1.75 \%$ from $800 \mathrm{~g}$ onwards. The feeding screen nets were changed bi-weekly and cleaned. The cages were lifted from water every week to check any damage. Daily observation was carried out throughout the experiment for cage net, drums, frame etc.

Regular sampling was done at 30days interval to determine the growth of fish by catching 30 fish from each cage and pond with the help of scoop net and seine net respectively. The growth in body length and weight was measured with the help of scale graduated in centimetres and a digital balance respectively.

At the end of each sampling, fishes were treated with $\mathrm{KMnO}_{4}$ solution ( 5 ppm) for half a minute to prevent infections. Water samples were analysed monthly from cage site of reservoir and each experimental pond. The water temperature was measured by the use of digital thermometer (Fisher Scientific) and $\mathrm{pH}$ was measured by using waterproof $\mathrm{pH}$ tester30, manufactured by EUTECH instruments, OAKTON. Dissolved oxygen (ppm) was measured by using standard Wrinkler's modified method (Strickland and parson, 1968). Total alkalinity and total hardness was estimated by using titrimetric method (APHA et al., 1998). Nitrate nitrogen, unionized ammonia - nitrogen and phosphate - phosphorous concentration was estimated spectrophotometrically at $543 \mathrm{~nm}$, $635 \mathrm{~nm}$ and $690 \mathrm{~nm}$ wavelength respectively by phenate method (APHA et al., 1998). The chlorophyll-a concentration was determined spectrophotometrically by measuring the absorbance (optical density-OD) of the extract at various wavelengths $(750,663,645$, and $630 \mathrm{~nm})$.

At the end of the seven months grow-out culture period, the ponds were harvested by seine netting and draining. Likewise, cages were harvested by scoop net after partially lifting of cage net. The gross production and net profit per unit volume were calculated. Specific growth rate (SGR), feed conversion ratio (FCR), survival rate and benefit cost ratio (BCR) were estimated by the following formulae.

Specific growth rate $=\frac{\ln (\text { final weight })-\ln \text { (initial weight) }}{\text { No. of culture days }} \times 100$

Feed conversion ratio $=\frac{\text { Feed fed }(\text { dry matter })}{\text { live weight gain }}$

Survival $(\%)=\frac{\text { Total no.of harvested animals }}{\text { Total no. of stocked animals }} \times 100$

Benefit cost ratio $=\frac{\text { Gross revenue }}{\text { Production cost }}$

The data were subjected to statistical analysis by using Microsoft Excel programme and SPSS programme for Windows (version 22.0). T-test was performed at 5\% significance level $(p \leq 0.05)$ to know the 
difference between the treatment means for different parameters of cage and pond.

\section{Results and Discussion}

P. hypophthalmus showed higher growth performance in cages as compared to ponds in terms of all the parameters. The features of different growth parameters are summarized in table 1 .

\section{Growth, survival, production and economic performance}

During seven months of rearing period, the mean body weight of $P$. hypophthalmus increased from $71.47 \pm 0.84 \mathrm{~g}$ to $1026.87 \pm$ $7.48 \mathrm{~g}$ in cages and $71.47 \pm 0.84 \mathrm{~g}$ to $975.84 \pm$ $7.21 \mathrm{~g}$ in ponds, the mean body length increased from $18.83 \pm 0.52 \mathrm{~cm}$ to $46.25 \pm$ $0.94 \mathrm{~cm}$ in cages and $18.83 \pm 0.52 \mathrm{~cm}$ to $45.06 \pm 0.79 \mathrm{~cm}$ in ponds. A comparison of growth performance of $P$. hypophthalmus undercage and pond culture system showed that the experimental fish grew differently and the growth response in terms of body weight and body length gain was higher in cages than ponds (Figs. 1 and 2).

During middle of the culture period, because of winter season, the low temperature $\left(20{ }^{\circ} \mathrm{C}\right)$ had more negative effect on pond culture of Pangasianodon hypophthalmus. Likewise, the specific growth rate (SGR) recorded was also higher in cages than ponds, as it was $1.27 \pm$ 0.007 in cage and $1.25 \pm 0.008$ in ponds (Fig. 4). Mwachiro et al., (2012) reported faster growth of a tilapine fish Oreochromisjipe in cages $(182.11 \mathrm{~g})$ than earthen ponds (165.18 g). Mensah et al., (2014) reported the same trend of increased growth of Oreochromis niloticus and Sarotherodon galilaeus in cages than hapa-in ponds as they recorded the final weight, final length and SGR was higher in cages than hapa-in ponds.
The feed conversion ratio (FCR) in the present study was $1.63 \pm 0.011$ in cages and $1.47 \pm 0.01$ in ponds, which showed better FCR achieved in ponds in comparison with cages (Fig. 4). However, Mensah et al., (2014) reported better FCR in cages than hapa-in pond. The lower FCR achieved in ponds may be due to presence of abundant natural food in the form of phytoplankton and zooplankton in the present study. The survival of the $P$. hypophthalmus in the present study was $90.91 \pm 0.93 \%$ in cages and $78.02 \pm 0.87$ $\%$ in ponds (Fig. 3), which supports the findings of Mensah et al., (2014), where higher survival was reported in cages as compared to ponds.

In the present study, the gross production per unit volume was $55.91 \pm 0.47 \mathrm{~kg} / \mathrm{m}^{3}$ in cages and $4.56 \pm 0.045 \mathrm{~kg} / \mathrm{m}^{3}$ in ponds and the net profit per unit volume achieved was $\square$ $1254.79 \pm 24.12$ per $\mathrm{m}^{3}$ in cages and $\square 57.59$ \pm 0.89 per $\mathrm{m}^{3}$ in ponds, which is in agreement with Mensah et al., (2014) as they reported higher gross production and net profit per unit volume in cages than hapa-in pond. In the present study, the benefit cost ratio (BCR) was $1.36 \pm 0.004$ in cages and $1.28 \pm 0.002$ in ponds, which is more or less similar as reported by Khan et al., (2009) and Debnath (2014). The present study reported ahigher BCR in cages as compared to ponds (Fig. 4).

\section{Water quality parameters}

Mean values of the different water quality parameters recorded from the experimental cages and ponds are shown in table 2 . In the present study average water temperature was $27.65 \pm 1.21$ and $26.19 \pm 1.62^{\circ} \mathrm{C}$ in cages and ponds respectively. According to Islam (1997), temperature ranging from $18.5-33^{\circ} \mathrm{C}$ was suitable for aquaculture.Also the water temperature in the range of $26.06^{\circ} \mathrm{C}$ to $31.97^{\circ} \mathrm{C}$ is suitable for fish culture as reported by Boyd (1982). 
Fig.1 Monthly growth comparison of Pangasianodon hypophthalmus between cages and ponds in terms of mean body weight $(\mathrm{g})$ during the grow-out culture period

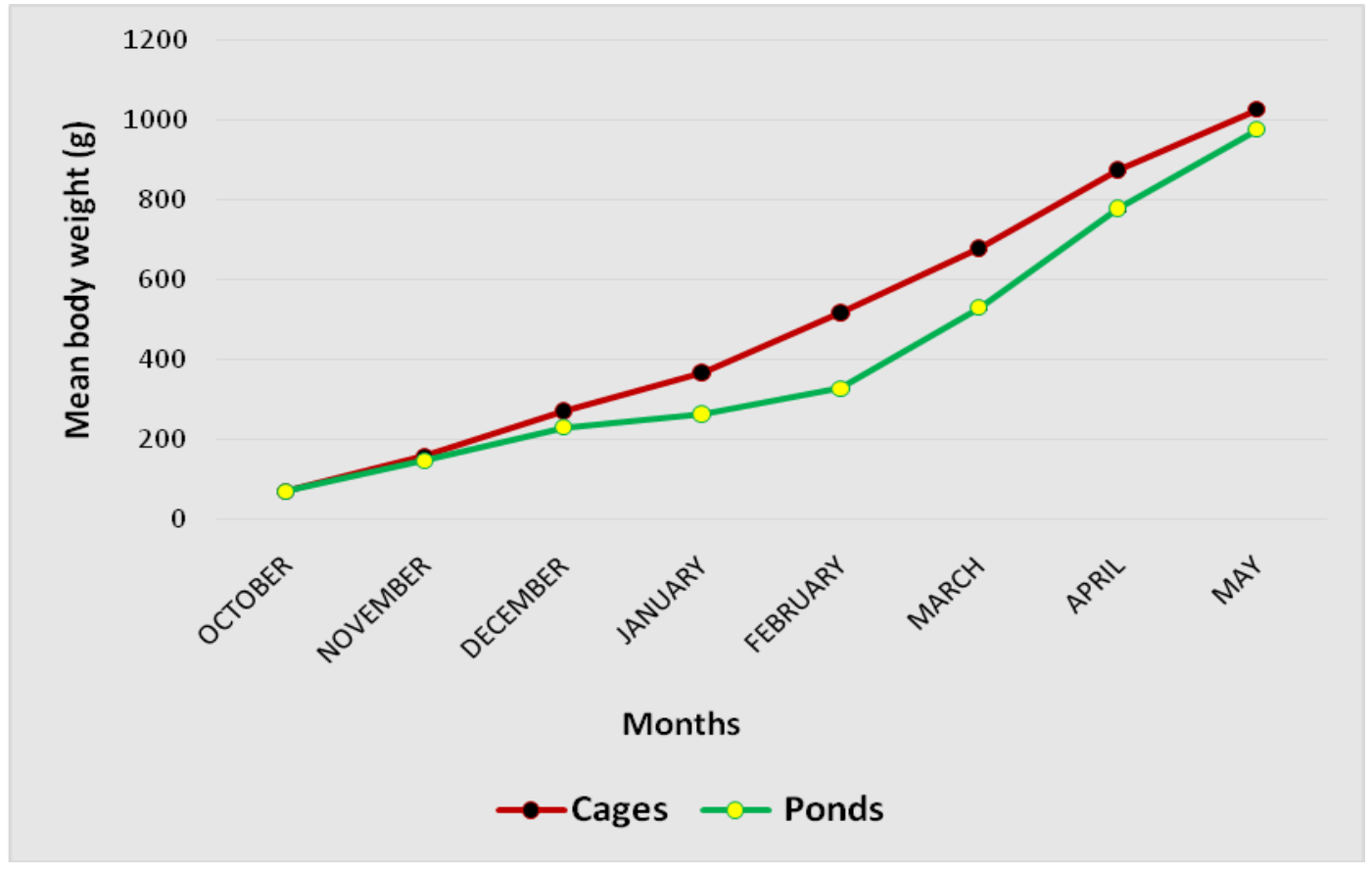

Fig.2 Monthly growth comparison of Pangasianodon hypophthalmus between cages and ponds in terms of mean body length $(\mathrm{cm})$ during the grow-out culture period

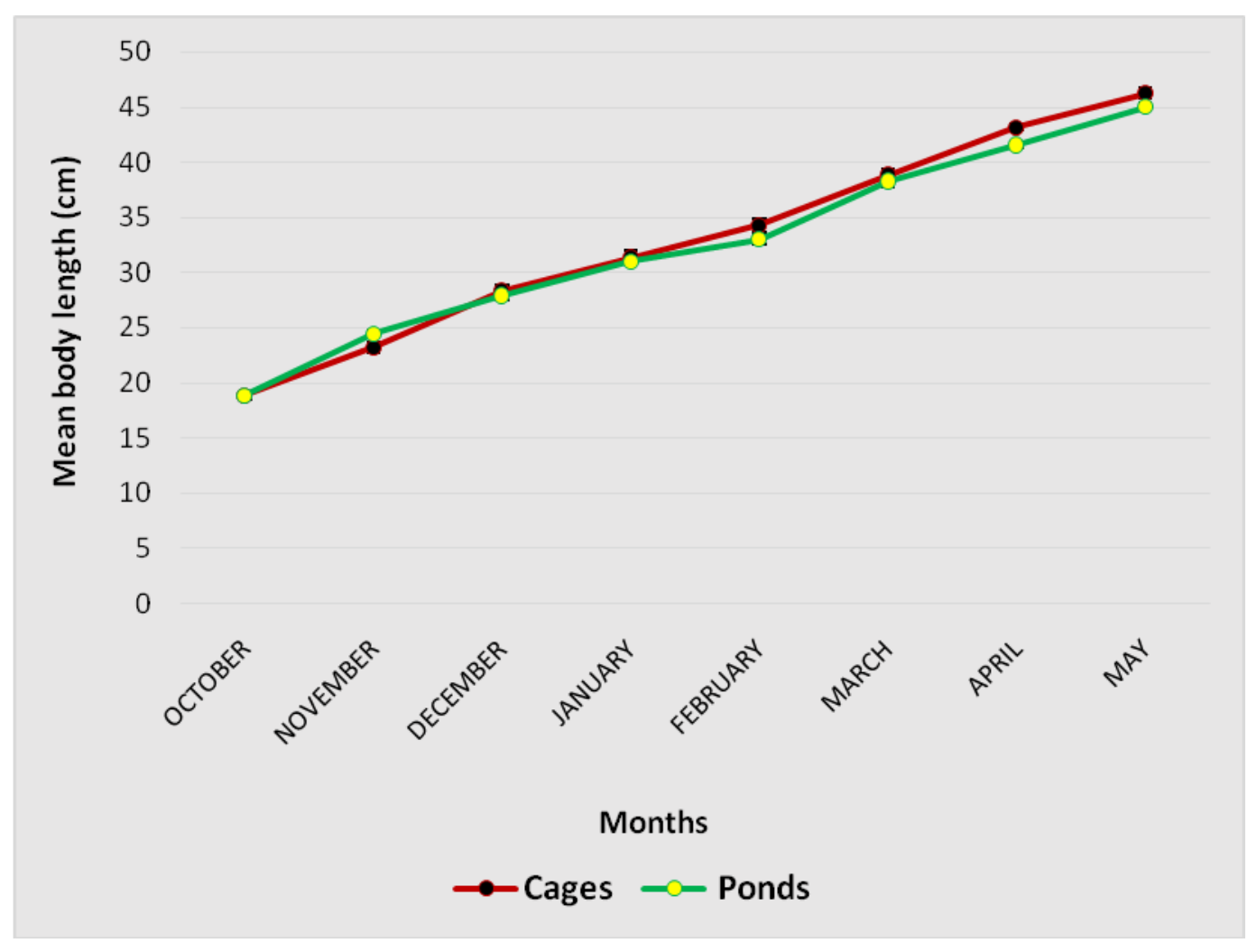


Fig.3 Comparison of Pangasianodon hypophthalmus survival (\%) between cage culture and pond culture

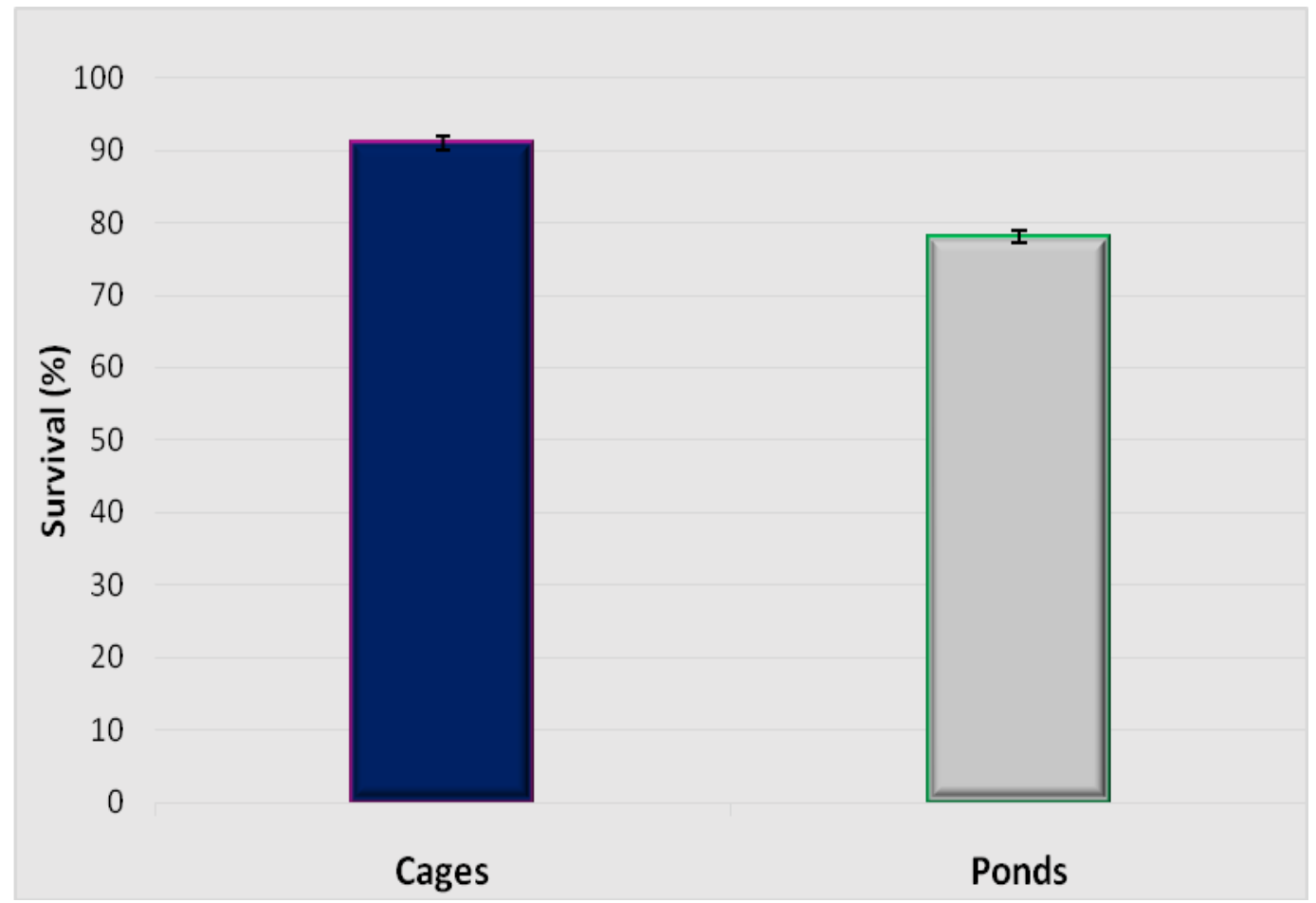

Fig.4 Comparison of specific growth rate (SGR), feed conversion ratio (FCR) and benefit cost ratio (BCR) between cage culture and pond culture of Pangasianodon hypophthalmus

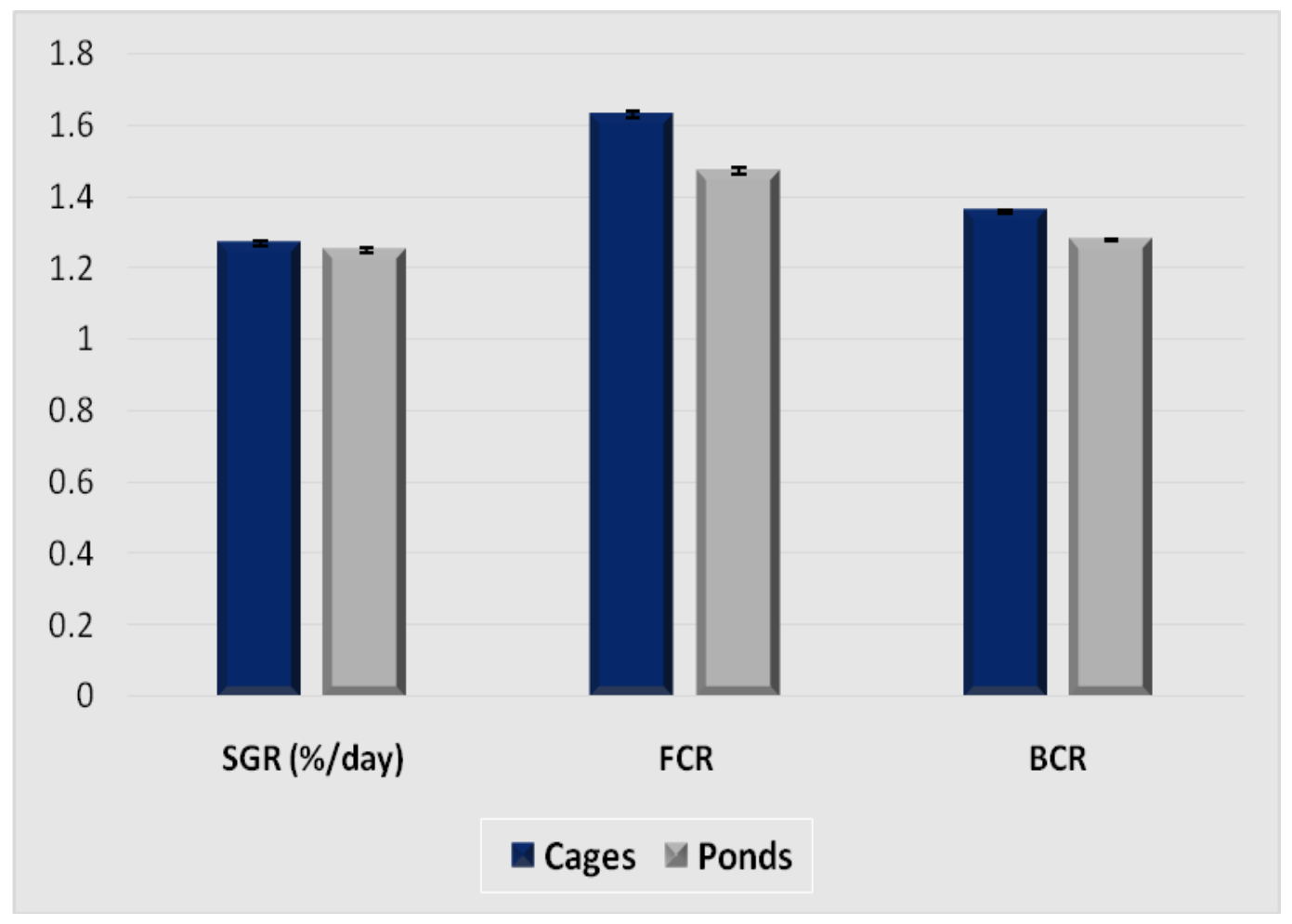


Table.1 Comparative growth, survival, production and economic performance of Pangasianodon hypophthalmus culture in cages and ponds

\begin{tabular}{|c|c|c|c|c|c|c|c|c|c|c|}
\hline \multirow{2}{*}{$\begin{array}{l}\text { Culture } \\
\text { system }\end{array}$} & \multicolumn{2}{|c|}{ Mean weight (g) } & \multicolumn{2}{|c|}{ Mean length $(\mathrm{cm})$} & \multirow{2}{*}{$\begin{array}{c}\text { SGR } \\
(\% / \text { day })\end{array}$} & \multirow[t]{2}{*}{ FCR } & \multirow{2}{*}{$\begin{array}{c}\text { Surviva } \\
1(\%)\end{array}$} & \multirow{2}{*}{$\begin{array}{c}\text { Gross } \\
\text { production } \\
\left(\mathbf{K g} / \mathbf{m}^{3}\right)\end{array}$} & \multirow{2}{*}{$\begin{array}{c}\text { Net } \\
\text { profit } \\
\left(\square / \mathbf{m}^{3}\right)\end{array}$} & \multirow[t]{2}{*}{ BCR } \\
\hline & \multicolumn{2}{|c|}{ Initial Final } & \multicolumn{2}{|c|}{ Initial Final } & & & & & & \\
\hline \multirow[t]{2}{*}{ Cage } & $\begin{array}{c}71.47 \\
+\end{array}$ & $\begin{array}{c}1026.87 \\
+\end{array}$ & $\begin{array}{c}18.83 \\
+\end{array}$ & $\begin{array}{c}46.25 \\
+\end{array}$ & $\begin{array}{c}1.27 \\
+\end{array}$ & $\begin{array}{c}1.63 \\
+\end{array}$ & $\begin{array}{c}90.91 \\
+\end{array}$ & $\begin{array}{c}55.91 \\
+\end{array}$ & $\begin{array}{c}1254.79 \\
+\end{array}$ & $\begin{array}{c}1.36 \\
\pm\end{array}$ \\
\hline & 0.84 & $7.48 *$ & 0.52 & $0.94 *$ & $0.007 *$ & $0.011 *$ & $0.93 *$ & $0.47 *$ & $24.12 *$ & $0.004 *$ \\
\hline \multirow[t]{2}{*}{ Pond } & $\begin{array}{c}71.47 \\
\pm\end{array}$ & $\begin{array}{c}975.84 \\
\pm\end{array}$ & $\begin{array}{c}18.83 \\
\pm\end{array}$ & $\begin{array}{c}45.06 \\
\pm\end{array}$ & $\begin{array}{c}1.25 \\
\pm\end{array}$ & $\begin{array}{c}1.47 \\
\pm\end{array}$ & $\begin{array}{c}78.02 \\
\pm\end{array}$ & $\begin{array}{c}4.56 \\
\pm\end{array}$ & $\begin{array}{c}57.59 \\
\pm\end{array}$ & $\begin{array}{c}1.28 \\
\pm\end{array}$ \\
\hline & 0.84 & $7.21 *$ & 0.52 & $0.79 *$ & $0.008 *$ & $0.010 *$ & $0.87^{*}$ & $0.04 *$ & $0.89 *$ & $0.002 *$ \\
\hline
\end{tabular}

Values of the parameters (Mean $\pm \mathrm{SE})$ in each row with $*$ differs significantly $(\mathrm{P}<0.05)$ and others are nonsignificant.

Assumptions

Seed cost $=\square 7.50$ /fingerling; Feed cost $=\square 34.00 / \mathrm{Kg}$; Labor cost $=\square 180.00 /$ day; Total fertilizer cost $=\square$ 4200.00; other cost $=\square$ 5000.00; Selling price $=\square 80.00 / \mathrm{Kg}$ fish.

Table.2 Variation (monthly interval) of water quality parameters in cages and ponds during seven months of grow-out culture period of Pangasianodon hypophthalmus

\begin{tabular}{|c|c|c|c|c|c|c|c|c|c|}
\hline $\begin{array}{l}\text { Water } \\
\text { quality } \\
\text { parameters } \\
(\text { mean } \pm \text { SE) }\end{array}$ & $\begin{array}{c}\text { Temp } \\
\left({ }^{0} \mathrm{C}\right)\end{array}$ & $\begin{array}{l}\text { Dissolved } \\
\text { oxygen } \\
\text { (mg/L) }\end{array}$ & pH & $\begin{array}{c}\text { Alkalinity } \\
\text { (mg/L) }\end{array}$ & $\begin{array}{c}\text { Hardness } \\
(\mathrm{mg} / \mathrm{L})\end{array}$ & $\begin{array}{l}\mathrm{NO}_{3}-\mathrm{N} \\
(\mathrm{mg} / \mathrm{L})\end{array}$ & $\begin{array}{l}\mathrm{NH}_{3}-\mathrm{N} \\
(\mathrm{mg} / \mathrm{L})\end{array}$ & $\begin{array}{l}\mathrm{PO}_{4}-\mathrm{P} \\
(\mathrm{mg} / \mathrm{L})\end{array}$ & $\begin{array}{c}\text { Chlorophyll- } \\
\mathbf{a} \\
(\mu \mathrm{g} / \mathrm{L})\end{array}$ \\
\hline Cage & $\begin{array}{c}27.65 \\
\pm \\
1.21\end{array}$ & $\begin{array}{c}7.76 \\
\pm \\
0.24\end{array}$ & $\begin{array}{c}7.2 \\
\pm \\
0.11\end{array}$ & $\begin{array}{c}125.16 \\
\pm \\
7.24\end{array}$ & $\begin{array}{c}106.56 \\
\pm \\
4.88\end{array}$ & $\begin{array}{c}0.07 \\
\pm \\
0.00\end{array}$ & $\begin{array}{c}0.12 \\
\pm \\
0.03\end{array}$ & $\begin{array}{c}0.46 \\
\pm \\
0.05\end{array}$ & $\begin{array}{c}41.19 \\
\pm \\
1.40\end{array}$ \\
\hline Pond & $\begin{array}{c}26.19 \\
\pm \\
1.62\end{array}$ & $\begin{array}{c}6.92 \\
\pm \\
0.17\end{array}$ & $\begin{array}{c}7.4 \\
\pm \\
0.08\end{array}$ & $\begin{array}{c}146.13 \\
\pm \\
8.03\end{array}$ & $\begin{array}{c}137.27 \\
\pm \\
6.15\end{array}$ & $\begin{array}{c}0.14 \\
\pm \\
0.01\end{array}$ & $\begin{array}{c}0.23 \\
\pm \\
0.02\end{array}$ & $\begin{array}{c}0.93 \\
\pm \\
0.06\end{array}$ & $\begin{array}{c}138.16 \\
\pm \\
1.34\end{array}$ \\
\hline
\end{tabular}

Dissolved oxygen content of the current study was7.76 \pm 0.24 in cages and $6.92 \pm 0.17 \mathrm{mg} / \mathrm{L}$ in ponds. Alikunhi et al., (1971) suggested that good native water for fish cultivation should have a fair amount of DO level ranging from 5 to $7 \mathrm{mg} / \mathrm{L}$. The $\mathrm{pH}$ recorded was $7.2 \pm 0.11$ in cages and $7.4 \pm 0.08$ in ponds.For pond fish culture the suitable range of $\mathrm{pH}$ is 6.5 to 8.5 (Boyd, 1990). The alkalinity recorded was $125.16 \pm 7.24 \mathrm{mg} / \mathrm{L}$ in cages and $146.138 .03 \mathrm{mg} / \mathrm{L}$ in ponds, likewise total hardness recorded was $106.56 \pm$ $4.88 \mathrm{mg} / \mathrm{L}$ in cages and $137.27 \pm 6.15 \mathrm{mg} / \mathrm{L}$ in ponds. Alikunhi et al., (1971) stated that total alkalinity more than $100 \mathrm{mg} / \mathrm{L}$ should be present in highly productive waters. Mondal et al., (2010) reported that a total alkalinity of 77.4 to $139.54 \mathrm{mg} / \mathrm{L}$ was best during fish culture. The recommended ideal value of hardness for fish culture is in a range of 30$180 \mathrm{mg} / \mathrm{L}$ (Singh and Santosh, 2007) and 50 $150 \mathrm{mg} / \mathrm{L}$ (Thomforde and Stone, 2004).

Nitrate and phosphate are the limiting factors for plant nutrient and are considered as the most important nutrients for fish culture. In the current study nitrate-nitrogen $\left(\mathrm{NO}_{3}-\mathrm{N}\right)$ was $0.07 \mathrm{mg} / \mathrm{L}$ in cages and $0.14 \pm 0.01 \mathrm{mg} / \mathrm{L}$ in ponds, ammonia-nitrogen $\left(\mathrm{NH}_{3}-\mathrm{N}\right)$ was $0.12 \pm 0.03 \mathrm{mg} / \mathrm{L}$ in cages and $0.23 \pm 0.02$ $\mathrm{mg} / \mathrm{L}$ in pondsand phosphate-phosphorus $\left(\mathrm{PO}_{4}-\mathrm{P}\right)$ was $0.46 \pm 0.05 \mathrm{mg} / \mathrm{L}$ in cages and $0.93 \pm 0.06 \mathrm{mg} / \mathrm{L}$ in ponds. $\mathrm{NO}_{3}-\mathrm{N}$ is more or less similar to the results of Bhuiyan (1970), who reported that the range of $\mathrm{NO}_{3}-\mathrm{N}$ from 0.06 to $0.1 \mathrm{mg} / \mathrm{L}$ is suitable range for fish culture. Chen (1988) found that lower than 1 $\mathrm{mg} / \mathrm{L} \mathrm{NH}_{3}-\mathrm{N}$ content in pond water was good 
for fish culture. Azim et al., (1995), Paul (1998) and Kohinoor (2000) reported $\mathrm{NH}_{3}$ Nin the range of 0.01 to $0.99 \mathrm{mg} / \mathrm{L}$. Hassan (1998) reported that the $\mathrm{PO}_{4}-\mathrm{P}$ ranged from 0.11 to $2.0 \mathrm{mg} / \mathrm{L}$ in earthen ponds. Islam and Shaha (1975) observed that phosphatephosphorus range from 0.2 to $2.8 \mathrm{mg} / \mathrm{L}$ is favorable for the growth of blue green algae and diatoms. The chlorophyll-a concentration was $41.19 \pm 1.40 \mu \mathrm{g} / \mathrm{L}$ in cages and $138.16 \pm$ $1.34 \mu \mathrm{g} / \mathrm{L}$ in ponds. It indicates that ponds were highly productive and suitable for fish culture, whereas, the reservoir also have good productive water where the cages were installed. The chlorophyll-a values recorded in the present study were more or less similar to that reported by Paul (1998) and Kohinoor (2000).

The present study may conclude that due to higher yield and more economic return, cage culture of $P$. hypophthalmus might be a more suitable option than pond culture. Good quality and large size fingerlings are essential for more production and better survival of $P$. hypophthalmus in cage aquaculture.

\section{Acknowledgement}

Authors wish to thank Dr. W. S. Lakra, Director of ICAR- Central Institute of Fisheries Education, Mumbai and Indepesca Aquaculture Pvt. Ltd. for their technical and financial support regarding this research programme.

\section{References}

Alikunhi, K.H., Sukumaran, K. K. and Parameswaran, S., 1971. Studies on composite fish culture. Production by compatible combinations of Indian and Chinese carps. J. Inland Fish. Assoc., 1: 26-57.

American Public Health Association (APHA), American Water Works Association
(AWWA), and the Water Environmental Federation (WEF), 1998. Standard Methods for Examinations of Water and Wastewater, $20^{\text {th }}$ ed. United Book Press, Inc. Baltimore, Maryland.

Azim, M. E., Talukder, G. S., Wahab, M. A., Haque, M. M. and Haq, M. S., 1995.Effect of liming and maintenance of total hardness levels on fish production in fertilized ponds. Progress. Agric., 6(2): 7-14.

Bhuiyan, B. R., 1970. Physico-chemical qualities of some ancient tanks of Sibsagar, Assam. Environmental Health, 12: 129-134.

Boyd, C. E., 1982. Water quality management for pond fish culture. Elsevier, the Netherlands, $318 \mathrm{pp}$.

Boyd, C. E., 1990. Water quality in ponds for aquaculture. Birmingham Publishing Company, Birmingham, Alabama, 482 pp.

Chaturvedi, C. S., Lakra, W. S., Singh, R. K. and Pandey, A. K., 2015. Successful induced breeding and larval rearing of Pangasianodon hypophthalmus under controlled condition of Raipur (Chhattisgarh). Biodiversity for Sustainable development, Uttar Pradesh State Biodiversity Board, p. 106-112.

Chen, I. C., 1988. Aquaculture in Taiwan. Fishing News Book, London, 273 pp.

Debnath, C., 2014. Evaluation of growth and production of Ompok bimaculatus (Bloch, 1794) in monoculture and polyculture with carps for aquaculture diversification and species conservation. Ph. D. Thesis, ICAR-Central Institute of Fisheries Education, Mumbai, 45 and $51 \mathrm{pp}$.

Hassan, M. A., 1998. Development of carp polyculture techniques with small indigenous fish species Mola (Amblypharyngodon mola), Chela (Chela cachius), Punti (Puntius 
sophore). M. S. dissertation. Department of Fisheries Management. Bangladesh Agricultural University, Mymensingh, $71 \mathrm{pp}$.

Islam, A. K. M. N., and Shaha, S. K., 1975 Limnological Studies of the Ramnalake at Dhaka. Dhaka Univ. Stud., (B); p. 39-48.

Islam, M.L., 1997. Impact of introduction of mola (Amblypharyngodon mola Ham.) in the polyculture with carps. M.S. Thesis, Department of Fisheries Management, BAU, Mymensingh, 41 pp.

Khan, S., Hossain, M.S. and Haque, M.M., 2009.Effects of feeding schedule on growth, production and economics of pangasiid catfish (Pangasius hypophthalmus) and silver carp (Hypophthalmichthys molitrix) polyculture. J. Bangladesh Agri. Univ., 7(1): 175-181.

Kohinoor, A. H. M., 2000. Development of culture technology three small indigenous fish mola (Amblypharyngodon mola), punti (Puntius sophore) and chela (Chela cachius) with notes on some aspects of their biology. A Ph.D. dissertation. Department of Fisheries Management, Bangladesh Agricultural University, Mymensingh. 363 pp.

Kohli, M.P.S., Ayyappan, S., Langer, R. K., Ogale, S. N., Dube, K., Prakash, C. and Reddy, A. K., 2004. Cage culture of mahseer, Tor khudree (Sykes) and Tor putitora (Ham) at Walvan reservoir, Lonavla, Maharashtra. Proceedings of National Seminar on Aquatic Resource Management in Hills. (Eds. K.K. Vass, S.A.H. Abidi and V.P. Agrawal) NRCM cold water fisheries and Society of Biosciences.

Kohli, M.P.S., Ayyappan, S., Langer, R. K., Dube, K., Prakash, C., Reddy, A. K. and Deshmukhe, G., 2002 Cage Culture of carps, $\quad$ Labeorohita and Cyprinus carpio in Powai lake. Applied Fisheries and Aquaculture, 2(2): 163-165.

Kohli, M.P.S., Dube, K., Langer, R. K., Prakash, C., Reddy, A. K., Tiwari, V. K. and Upadhyay, R. K., 2004 Cage Aquaculture in Open Waters Fishing Chimes, pp. 22-24, 61-62.

Lakra, W., and Singh, A., 2010.Risk analysis and sustainability of Pangasianodon hypophthalmus culture in India. Aquaculture Asia, 15(1): 34-37.

Mensah, E.T., Attipoe, F.K and Atsakpo, K., 2014. Comparative growth study of Oreochromis niloticus and Sarotherodon galilaeus under two different culture regimes (Hapa-In-Pond and cage systems). International Journal of Fisheries and Aquatic Studies, 1(5): 53-59.

Mondal, M.N., Shahin, J., Wahab, M. A., Asaduzzaman, M. and Yang, Y., 2010.Comparison between cage and pond production of Thai Climbing Perch (Anabas testudineus) and Tilapia (Oreochromis niloticus) under three management systems.J. Bangladesh Agri. Univ., 8(2): 313-322.

Mwachiro, E. C., Makilla, D., Bett, D. K. and Ndeje, G. K., 2012.A Comparative Study of Cage and Earthen Pond Culture of Oreochromis jipe, In Lake Jipe, Taita/Taveta District, Kenya. Global Advanced Research Journal of Agricultural Science, 1(7): 163-181.

Paul, S., 1998. Comparison between carp polyculture system with silver carp (Hypophthalmichthyes molitrix) and with small indigenous fish mola (Amblypharyngodon mola). An M. S. thesis. Department of Fisheries Management, Bangladesh Agricultural University, Mymensingh, $85 \mathrm{pp}$.

Singh A. K., and Lakra W. S., 2012. Culture of Pangasianodon hypophthalmus into India: Impacts and present Scenario. 
Pakistan journal of biological Sciences, 15 (1): 19-26.

Singh, N. P., and Santhosh, B., 2007. Guidelines for water quality management for fish culture in Tripura, ICAR Research Complex for NEH Region, Tripura Center, Publication no. 29.

Strickland, J.D.H., and Parsons, T.R., 1968. Determination of dissolved oxygen. A
Practical Handbook of Seawater Analysis. Fisheries Research Board of Canada, Bulletin, 167: 71-75.

Thomforde, H. K., and Stone, N. M., 2004. Understanding Your Fish Pond Water Analysis Report. Co-operative Extension Program, University of Arkansas at Pine Bluff Aquaculture /Fisheries.

\section{How to cite this article:}

Manish Kumar, Kiran Dube, V.K. Tiwari, A.K. Reddy and Chaturvedi, C.S. 2017. Comparative Performance of Pangasianodon hypophthalmus (Sauvage, 1878) Culture in Cages and Ponds. Int.J.Curr.Microbiol.App.Sci. 6(10): 1679-1688.

doi: https://doi.org/10.20546/ijcmas.2017.610.203 